\author{
Sh.M. Mazhitaeva ${ }^{1}$, D. Vesselinov ${ }^{2}$, D. Ye. Amanbekova ${ }^{1}$ \\ ${ }^{1}$ Karagandy University of the name of academician E. A. Buketov, Kazakhstan; \\ ${ }^{2}$ Sofia University «St. KlimentOhridski», Bulgaria \\ (E.mail:s_mazhit@mail.ru,d_vesselinov@yahoo.fr,yerglievna@mail.ru)
}

\title{
Language representation and the structure of concepts in the modern cultural linguistics
}

\begin{abstract}
The term «concept» is considered from the point of view as a new science that has emerged within the framework of the anthropocentric paradigm - linguoculturology. The characteristic features of concepts with different semantic components in structure and character are analyzed. The article generalizes the presence of an image-associative layer of concepts - one of the most important features that differs from the term and has the necessary communicative and semantic representation. On the basis of this study, the authors have proposed viewing concepts as a structure consisting of the inter-zone, extra-zone, quasi-zone and quasientropy. It is revealed that the means of the concepts representation, which is the center of the conceptual layer of language consciousness, around which additional layers are grouped. Associative vectors diverge from the «value-accented point of consciousness». The language or speech unit, with the help of which is updating the «Central point» of the concept.
\end{abstract}

Keywords: concept, the structure of the concept, conceptual analysis, linguistic culturology, the representation of concepts, scheme, frame, scenario, gestalt, linguistic, cognitive approach.

The modern period of linguistics development coincides with the development of cognitive sciences. The concept problem is a promising area of cognitive linguistics research. Language was the main object of research at the initial stages of the cognitive linguistics formation. Over time T. Bever, J. Carroll and L. Miller and many other linguists have introduced «cognition research» to the program of cognitive science, and these studies often have both philosophical and purely engineering scientific aspects».

The transformation-generative or gendering grammar of Naom Chomsky had a great influence on the cognitive linguistics development. He first identified problems related to cognition: 1) the problem of the nature of knowledge and what it is; 2) the problem of the origin of knowledge systems. Chomsky distinguished between linguistic competence, which is considered a field of linguistics, and linguistic performance, which is a field of psychology.

Russian scientists V.Z. Demyankov and E.S. Kubryakova believe that «cognitive linguistics studies language as a cognitive mechanism that plays a role in encoding and transforming information».

According to the opinion of E.S. Kubryakova, today there is a tendency of bringing the study of cognitive science closer to the study of language. However, neither cognitology turns only into the science of language, nor linguistics into the science of cognition. The linguist in her research is faced with the problems of identifying not only the linguistic forms behind speech activity, but also how language units can be associated with the perception of the world and its cognition.

The description and explication of the internal cognitive structure the «speaker - listener», according to V.Z. Demyankov, is the central task of cognitive linguistics. The proposed structure should be interpreted as a system of information processing, which consists of a certain number of independent components, comparing language information at different levels. The aim of the cognitive linguistics research is studying of the system and definition of its main principles and not only in the reflection of language phenomena in the cognitive structure.

Z.D. Popova and I.A. Sternin understand cognitive linguistics as «the study of mental processes occurring during perception, comprehension and, consequently, cognition of reality by consciousness, as well as the types and forms of their mental representations» [1; 267]. Scientists emphasize in their works the difference between cognitive linguistics and other cognitive sciences. Firstly, in their opinion, the difference is in its material, because cognitive linguistics studies consciousness on the material of language, and any other cognitive science studies consciousness on its material. Secondly, the difference is in the methods that they use. Cognitive linguistics studies cognitive processes, makes conclusions about the types of mental represen- 
tations in the human mind based on linguistic analysis methods, and at the end of the work conducts a cognitive interpretation of the research results.

This research is aimed at studying collective consciousness on the material of language using psycholinguistic methods. The material of the linguo-cognitive analysis is the language, so the purpose of our work is identifying functioning patterns of the concepts «poverty» and "wealth» in the language consciousness of young people and to model the content and structure of the studied concepts as units of national consciousness (concept sphere).

The notion of the concept sphere is at the center of cognitive linguistics, it is: «a field of knowledge composed of concepts as its units». The central category of the cognitive linguistics is connected with the term «concept». The term «concept» is an umbrella term, because it covers the subject areas of several scientific areas: «primarily cognitive psychology and cognitive linguistics, dealing with the problems of thinking and cognition, storage and processing of information».

I.A. Sternin defines concepts as «units of thought, which in their content and organization can be very different while maintaining their main functions - to structure knowledge and act as units of the thought process. The typology of concepts is possible and necessary due to the fact that there are different types of knowledge represented by concepts». Scientists of various schools and directions consider the issue of concepts typology from their own point of view, but basically all scientific schools distinguish traditional types of concepts: representation, scheme, concept, frame, scenario, and gestalt.

The introduction of our work can be described according to A.P. Babushkin offers the following classification of concepts: frames can be expressed in the image of a situation (market, hospital, museum), scenarios imply the idea of an event (a fight, a lecture), mental images break up into premonitory realities or mythemes (daisy, rooster, death, devil), schemes suggest the use of words with a «spatial» meaning (river, road, tree), hyperonyms reflect Hypo-hyperonymic relations in the vocabulary (shoes: shoes, boots), insights contain information about the structure, function of the object (umbrella, drum, scissors), «kaleidoscopic concepts» are developed in the form of one or another of the structures mentioned above and represent concepts of abstract names of social orientation (duty, decency, conscience).

With this in mind, types of concepts identified by N.N. Boldyrev, in fact, have much in common with the types of concetts proposed by A.P. Babushkin, however, in most cases N.N. Boldyrev uses other terms $[1 ; 268]$.

A very significant step, according to V.N. Telia, is the introduction of the notion of «prototype» or Gestalt structures into the description. Under these concepts lies what has always been referred to as a representation, i.e., a more concrete form of reflection than a concept (ideal formation) - something like a «picture» with minor details omitted while preserving essential ones. In the concept of psychologists, this is a stereotype (for example, for the Russian consciousness, a small bird is a Sparrow, and for the English - a Robin []). The concept of a prototype intersects with two concepts: what psychologists call a typical image (a stereotype, a standard), and what linguists usually associate with a denotation, i.e., a «representative» of a class (or set) of objects selected for the nomination. Cognitive scientists have shown how important is the role of prototypes in the categorization of reality, while linguists have always meant by representation a certain entity, the " gap « between a non-linguistic reality and a concept. It is enough to note that all dictionaries fix the value exactly to the class, not the referent $[2,52]$.

M. Minsky interprets the frame as a static, informational structure of data necessary for the stereotypical situation representation. The frame content is a collection of vertex and terminal components. «The top levels» can always be clearly recognized, because they are formed by General, obvious concepts that are always true in relation to the stereotypical situation. «Low levels» contain terminal components that relate to characteristic examples and data [3].

Linguo-cultural concept may be considered by the different bases. Linguoculturologists classify concepts as national, civilizational, individual, microgroup, macrogroup. Researchers identify concepts that function in one or another form of discourse: pedagogical, political, medical. The cultural direction divides the study of concepts according to the subject of the concept: emotional, educational, textual conceptosphere. Scientists V.I. Karasik and G.G. Slyshkin emphasize that the frame, scenario, script have a clearer structure than the concept, and can be used in research to model the concept [4].

Representatives of linguistic and cognitive approach distinguish the following types of concepts: the representation is expressed as a generalized sensual-visual images of phenomena; the scheme are concepts that some generalisedspatio-graphical schema; notion - concept, which consists of general, essential features of the object and phenomenon, the result of their rational reflection and understanding. Concepts are 
verbalized by terminological and industrial vocabulary, as well as by lexemes of rational semantics such as resident, client; frame - a multi - component concept, a three-dimensional representation, a certain set of standard knowledge about a subject or phenomenon; scenario (script) expresses a sequence of several episodes in time; Gestalt-a complex, integral functional mental structure that orders the variety of individual phenomena in consciousness.

Scientists also offer the following division of concepts:

1. According to the degree of stability, there are stable (regularly verbalized in standard language form) and unstable (irregularly or not at all verbalizable) concepts;

2. According to ability of observation, concepts can be verbalized and non-verbalized. Verbalized concepts are concepts for which there are regular language means of expression in the system, non-verbalized, hidden-not verbalized or artificially verbalized only in the conditions of a forced task (for example, in an experiment);

3. According to the degree of the content abstraction, they are divided into abstract and concrete [4].

A.V. Rudakova offers the next classification of concepts:

1. According to the frequency and regularity of updating, there are current and outdated concepts. Current concepts are communicatively relevant, they are regularly verbalized, and they are necessary for both thinking and communication. Outdated concepts are needed mainly for thinking, they are rarely verbalized;

2. According to the method of language expression of the verbalizing units, they speak about lexicalphraseological, grammatical and syntactic concepts. And, among lexical and phraseological concepts, oneword (verbalized by a single lexeme), ambiguous (verbalized by stable phrases) and textual (verbalized by an entire text);

3. There are structural types of concepts. A single-level concept has only a sensory core, one base layer, for example: «yellow», «salty», «spoon», «plate». The multi-level concept includes several cognitive layers: the core, base layers, and peripherals. The concept can be segmented, represent a basic sensory layer surrounded by several segments equal in degree of abstraction (the concept of «tolerance») $[5,123]$.

There are two types of concepts for understanding the essence of phraseological meaning in relation to actual reality:

1) Logical concepts-mental formations that replace an indefinite set of homogeneous objects in the mind - a cognitive substrate, usually directly nominative lexical meanings;

2) Onomato-poietic concepts are mental formations that do not have a strictly deterministic connection with actual reality and do not obey the laws of logic - a cognitive basis for the formation of various figurative words meanings, semantics of paraphrases and phraseological units.

E.A. Selivanova includes the following components to the mental-psychonetic complex: a verbalized component of thinking, including language knowledge that exists in a language form, or in the form of text, discursive information and representing any ways of describing the world (scientific, artistic, folklore), reflected in our conceptual model; a non-verbalized component of thinking (experimental, figurative, mathematical knowledge, knowledge of culture, art, etc.); images (gestalts) that can have a non-verbal and verbal status; mental functions: feelings, sensations, intuition, transcendence, which correlate with thinking in thought-cognitive processes, including the use of language; reflexes in the mental-psychonetic complex, which have archetypes of the collective unconscious.

The issue of the structure of the concept is discussed by many scientific schools. Likhachev divides concepts into individual, group, universal, and ethnic [6,90]; in some works, concepts have a slightly different classification: lexical, syntactic, phraseological. In the framework of the culturological approach Askoldov distinguishes two types of concepts: cognitive and artistic.

The results of discussion can be viewed by the linguoculturological direction, the structure of the concept is presented from various levels, «layers», which are the result of the cultural, social life of different centuries. According to Stepanov the concept is formed by three main components or three layers:

1.a feature relevant to a given culture that exists for all who use this language;

2.an additional, or several «passive» or «historical» features, they exist only for some social groups, and passive features are actualized mainly when people communicate within this social group;

3.an internal form or an etymological feature, usually not at all conscious, captured in an external verbal form (this etymological feature is revealed only to researchers). Moreover, the literal meaning is always the starting point of the development of the concept in mental reality [1].

Nikitin correlates the layers of the concept with the modes (aspects) of the concept in the «Course of Linguistic Semantics»: 
1. The logical mode of the concept, which is manifested in the operations of classification and systematization of entities.

2. The normative mode of the concept (the value layer of the concept) consists of qualitatively varying attributes that are axiologically significant.

3. Polar axiological modes (optimal and anti-optimal) are on the edges of the scale with oppositely directed feature quality vectors in the field of positive or negative ratings.

4. Figurative mode of the concept (sensory-objective layer of the concept), which is presented as a generalized concrete construct of consciousness.

5. The emotional mode of the concept (the evaluation layer of the concept) contains those characteristics that are conditioned by the emotional-evaluative perception and experience of the class $[3,110]$.

Concept as a structure consisting of four zones: intrazone, extrazone, quasizone and quasi-electrozone. Intrazone is the features of the concept, reflecting its own signs of denotatas; the extrazone includes signs extracted from paremias and figurative meanings. Quasi-intrazone and quasi-extrazone are associated with formal associations resulting from the consonance of the concept name with another word, using euphemisms.

The structure of the linguistic and cultural concept consists of three components. In its composition, a figurative-perceptual component, a conceptual (informational-factual) component and a value component can be distinguished. The informational-factual or conceptual element of a concept can be objectified in language and directly reproduced in speech, the figuratively perceptual component is nonverbal in nature and can only be described.

The concept consists of a core and periphery, which includes less significant associations. The value component is the center of the conceptual layer of linguistic consciousness, around which additional layers are grouped. Associative vectors diverge from the «value-accentuated point of consciousness». The language or speech unit with which the "central point» of a concept is actualized serves as the name of the concept. However, the concept has no clear boundaries, since the gradual attenuation of associations occurs with distance from the core» $[7,39]$.

Strong and weak associative features are based on associations of various kinds, which can be stereotyped (or predictable) and free. At the same time, stereotypical associations appeal to some precedent phenomenon and are fixed in the form of frame structures (conventionality, frame typicality), while free, as a rule, are individual, personal or «single» representation [8].

As part of the linguistic-cognitive approach, researchers also propose to consider the field model of the concept. The structure of the concept can be represented in the form of an associative model consisting of a core, base layers and periphery. The core may include the most vivid images that have sensory-visual concreteness. The concept is encoded in the mind in an individual sensory way, which is the basic unit of a person's universal subject code. The sensual image underlying the concept performs coding, symbolic functions for the concept as a whole. «Internal speech works on this code, which has the ability to move from internal control to external, relying on the entire sensory palette through visual representations» []. Around the core, the so-called base layers are grouped, and the features here develop in the direction from less abstract to more abstract. More abstract features make up the periphery of the concept. On the periphery there is an «interpretational field of the concept», representing the interpretation of the distinguished conceptual features and their combinations in the form of statements, attitudes of consciousness arising in this culture from the mentality of different people. The concept is not rigidly structured: it consists of conceptual attributes that form various conceptual layers.

According to scientists, it is necessary to distinguish between the content of the concept and the structure of the concept representation. The content of the representation concept is internally ordered according to the field principle:

corea prototype unit of the CPC (it can be either nationwide, as well as group and individual);

base layers enveloping the core in sequence from less abstract to more abstract;

the interpretation field of the concept, containing assessments and interpretations of the content of the core of the concept by national, group and individual consciousness $[1 ; 275]$.

Sternin and Popova emphasize that the basic structural components of the concept - the image, information content and interpretation field - are distributed across different field sections of the concept, while there is no rigid fixation of the structural components of the concept to certain field zones - thus, the information content of the concept can belong to both the core and the near periphery, and to other zones of the periphery, and signs of the interpretation field can enter the core of the concept in brightness. 
The original structure identifies three aspects in the structure of the concept: mental (in other words, cognitive), semantic (linguistic) and psychic. The researcher considers the model of the mental-psychonetic complex as an integrative, systemically organized entity, correlating with the concept system, consciousness, collective unconscious. The researcher sees the purpose of conceptual analysis in modeling the mentalpsychonetic complex using the sign system of the language. The core of the mental-psychonetic complex is the cognitive frame model, which has a diffuse verbal-non-verbal mental nature and is associated with other mental functions of consciousness.

The concept is represented by conceptual, substantive, associative and evaluative components. The scientist believes that, depending on the type of activity, different components of the concept may be actualized, giving rise to meanings [3].

An interesting approach to the classification of concepts is presented in the research of Gurevich, who distinguishes two groups of concepts:

1) «cosmic» concepts, which are universal categories of culture (cause, time, change, space, movement);

2) «social» concepts, which have cultural characteristics (labor, wealth, property, freedom, law, justice).

Maslova adds one more to these groups of concepts - the concept of national culture (will, share, soul, intelligence). In the process of analyzing concepts, the researcher comes to the conclusion that concepts of a national character or national specificity prevail in the linguistic cultures of many countries.

In modern methods, there are a sufficient number of methodological techniques used in the study of concepts. Each researcher uses a method that is relevant to him.

In addition to these methods, it is worth mentioning the methods of studying cultural concepts: analysis of proverbs, maxims, aphorisms, the internal form of words, precedent texts, plots of the most famous works of art, in particular books and films, various codes, as well as a psycholinguistic experiment with native speakers to identify the most typical associations associated with certain concepts (questionnaires, interviews) $[8 ; 156]$.

In conclusion, we can see that linguoculturological research by nature involves a comparison of the phenomena studied, but such a comparison can be twofold: 1) a contrastive analysis of language units expressing a national-specific vision of the world in compared linguocultures and 2) a typological analysis of such units, which involves building on a deductive basis models of culturally significant relationships, for example, in the form of a matrix, and the definition of linguistic methods for the selective filling of such a matrix. In the first case, the study should be based on data obtained from several, at least two, languages; in the second case, an appeal to the factual account of one language seems quite justified.

A huge contribution to the study of the content and structure of concepts was made by Popov and Sternin. They developed a system of methods for reconstructing linguistic consciousness, which includes:

1. The choice of a keyword for research;

2. The construction and analysis of the semantem of the keyword verbalizing the concept in the language. To construct the semantem of the key token, it is necessary to identify all the sememes that it is capable of designating; examples from various texts are added to dictionary materials; it is useful to refer to the analysis of the etymology of the word, which allows you to disclose the process of development and formation of the semantem of the keyword.

3. The analysis of the lexical compatibility of the keyword;

4. The experimental methods:

a. free associative experiment. The method of a free associative experiment is that the subjects are offered stimulus words to which they must respond with any verbal reaction that comes to their mind. This method allows you to identify the greatest number of different features of the concept; the frequency of reactions indicates their relevance / irrelevance in the consciousness of the subjects;

b. receptive experiment is an experimental study of knowledge (understanding) of the meaning of a language unit by native speakers; its purpose is to study knowledge, understanding of the meaning of a language unit by native speakers. In this case, various methods can be used (for example, the subjects are asked to give their own definition of the meaning of the word; name words that are close in meaning and words that are opposite in meaning; describe the visual image that causes the word; choose the word that is most suitable for the proposed definition, etc.);

5. The analysis of the synonyms of the keyword; analysis of synonyms allows you to identify the differential features of the studied concept, revealed in the comparison of tokens belonging to the synonymous series; 
6. The construction of the key lexeme field (lexical-semantic or lexical-phraseological fields);

7. The construction of the derivation field of the key token;

8. The construction the lexical and grammatical field of the keyword;

9. The analysis of paremias and aphorisms, objectifying the concept in the language;

10. The analysis of literary texts;

11. The analysis of oral, colloquial usage;

12. The contrastive analysis of means of different languages; comparison of semantic features reveals the national specificity of equivalent concepts of different languages;

13. The comparative analysis of the lexical fields of different languages;

14. The methods for identifying syntactic concepts [8].

As a result, the study of frame structures obtained as a result of the application of the conceptual modeling method allows one to penetrate deeper into the semantic space of linguistic meanings and structures of knowledge, into various kinds of mental spaces.

\title{
References
}

1 Аскольдов С.А. Концепт и слово / С.А. Аскольдов // Русская словесность. От теории словесности к структуре текста: Антология. - M.: Academia, 1997. - С. 267-279.

2 Бабушкин А.П. Концепты разных типов в лексике и фразеологии и методика их выявления / А.П. Бабушкин // Методологические проблемы когнитивной лингвистики. - Воронеж: ВГУ, 2001. — С. 52-57.

3 Болдырев Н.Н. Когнитивная семантика: Курс лекций по английской филологии / Н.Н. Болдырев. - Тамбов: ТГУ, 2001. - $123 \mathrm{c}$.

4 Карасик В. Языковой круг: личность, концепты, дискурс / В. Карасик. - Волгоград: Перемена, 2002. — 477 с.

5 Попова 3.Д. Семантико-когнитивный анализ языка / З.Д. Попова, И.А. Стернин. - Воронеж: Истоки, 2006. - 226 с.

6 Мажитаева Ш.М. Передача скрытого значения при помощи знаков / Ш.М. Мажитаева // Вестн. РУДН. Сер. Теория языка. Семиотика. Семантика. - Вып. 4. — 2013. - С. 90-97.

7 Манкеева Ж. Қазақ тілін зерттеудің когнитивтік негіздері / Ж. Манкеева // Тілтаным. — Бас. 4. — Алматы, 2002. — Б. $39-43$.

8 Қайдар Ә. Қазақ тілінің өзекті мәселелері / Ә. Қайдар. - Алматы: Анатілі, 1998. — 304 б.

\section{Ш.М. Мажитаева, Д. Веселинов, Д.Е. Аманбекова \\ Қазіргі лингвомәдениеттегі тұжырымдамалардың тілдік репрезентациясы және кұрылымы}

\begin{abstract}
Мақалада ұғымнан ерекшеленетін және қажетті коммуникативті-мағыналық репрезентацияға ие маңызды белгілердің бірі - бейнелі-ассоциативті тұжырымдамалардың болуы туралы түсінік берілген. Антропоцентрикалық парадигма - лингвомәдениеттану аясында пайда болған жаңа ғылым тұрғысынан «тұжырымдама» ұғымы қарастырылған. Семантикалық компоненттердің сипаты мен тұжырымдамалардың құрылымына тән ерекшеліктері бойынша талданған. Жүргізілген зерттеу негізінде авторлар тұжырымдамаларды интерзона, экстразона, квазизона және квазиэкстразонадан тұратын құрылым ретінде қарастыруды ұсынған. Тұжырымдамаларды репрезентациялау құралдары анықталған, олар тілдік сананың тұжырымдамалық тобының орталығы болып табылады, яғни айналасына қосымша топтарды топтастырады. «Сананың құндылықты-акцентті нүктесінен» ассоциативті векторлар тарайды, ал тілдік немесе сөйлеу бірлігі тұжырымдаманың «орталық нүктесін» өзектендіреді.
\end{abstract}

Кілm сөздер: тұжырымдама, тұжырымдама құрылымы, лингвомәдениеттану, тұжырымдамалық талдау, тұжырымдамалардың репрезентациясы.

\author{
Ш.М. Мажитаева, Д. Веселинов, Д.Е. Аманбекова
}

\section{Языковая репрезентация и структура концептов в современной лингвокультурологии}

В статье обобщено наличие образно-ассоциативного слоя концептов - одного из важнейших признаков, по которому отличается от понятия и обладает необходимой коммуникативно-смысловой 
репрезентацией. Рассмотрено понятие «концепт» с точки зрения новой науки, возникшей в рамках антропоцентрической парадигмы, - лингвокультурологии. Проанализированы характерные особенности концептов, различные по структуре и по характеру. На основе проведенного исследования авторами предложено изучение концептов как структуры, состоящей из интерзоны, экстразоны, квазизоны и квазиэкстразоны. Выявлены средства репрезентации концептов, которые являются центром концептуального слоя языкового сознания, вокруг которого группируются дополнительные слои. От «ценностно акцентуированной точки сознания» расходятся ассоциативные векторы, а языковая или речевая единица актуализирует «центральную точку» концепта.

Ключевые слова: концепт, структура концепта, концептуальный анализ, лингвокультурология, репрезентация концептов.

\section{References}

1 Askoldov, S.A. (1997). Kontsept i slovo [The concept and the word]. Russkaia slovesnost. Ot teorii slovesnosti $k$ strukture teksta. Antolohiia - Russian literature. From the theory of literature to the structure of the text. Anthology]. Moscow: Akademiia [in Russian].

2 Babushkin, A.P. (2001). Kontsepty raznykh tipov v leksike i frazeolohii i metodika ikh vyiavleniia [Concepts of different types in vocabulary and phraseology and methods of their identification]. Metodololohicheskie problemy kohnitivnoi linhvistiki Methodological problems of cognitive linguistics. Voronezh: VHU [in Russian].

3 Boldyrev, N.N. (2001). Kohnitivnaia semantika [Cognitive semantics]. Tambov: THU [in Russian].

4 Karasik, V. (2002). Yazykovoi kruh: lichnost, konsepty, diskurs [Language circle: personality, concepts, discourse]. Volgograd: Peremena [in Russian].

5 Popova, Z.D., \& Sternin, I.A. (2006). Semantiko-kohnitivnyi analiz yazyka [Semantic and cognitive analysis of language]. Voronezh: Istoki [in Russian].

6 Mazhitaeva, Sh.M. (2013). Peredacha skrytoho znacheniia pri pomoshchi znakov [The transfer of latent values using the digits]. Vestnik RUDN. Seriia Teoriia yazyka. Semiotika. Semantika - Bulletin RUDN. Ser. Theory of language. Semiotics. Semantics, Is. 4, 90-97 [in Russian].

7 Mankeeva, Zh. (2002). Qazaq tilin zertteudin kognitivtik negizderi [Cognitive basics of learning the Kazakh language]. Tiltanym - Linguistics, Is. 4, 39-43. Almaty [in Kazakh].

8 Qaidar, A. (1998). Qazaq tilinin ozekti maseleleri [Current problems of the Kazakh language]. Almaty: Ana tili [in Kazakh]. 